\title{
Camels in Star Mythology and in Everyday Rural Life: Ethnographic Observations in South-West Arabia's Tihāma Lowlands
}

This short chapter discusses certain local south-west Arabian notions about the dromedary. These are connected with star lore among groups of inhabitants of the coastal plain along the eastern shores of the Red Sea, i.e. the Tihāma. Similar to other regions of the Middle East, local residents of rural areas in the Saudi and Yemeni Tihama often tend to attribute anthropomorphic qualities to camels. They are seen as strong and enduring, but also as unpredictable and unevenly tempered. With regard to several aspects of relations to the environment, dromedaries are perceived as being much more sensitive than humans. This obviously includes their ability to notice the proximity of moisture and water.

In the winter of 1981/82, during the third phase of a joint Saudi-Austrian ethnographic field work project, several elderly gentlemen living near the villages of Khamis al-Qawz and Dawqa 'l- 'Ula (about $200 \mathrm{~km}$ south of Jidda) told me independently of each other that the camel's behavior informed them each year in advance when the summer period of drought would come to a close and when the Pleiades would return. ${ }^{1}$ The ways in which these accounts were presented featured a curious combination of pragmatic experience and mythological symbolism. In this contribution I will contextualize, examine, and unpack these folk concepts about the camel. I will begin with a section on camels' usage in their material contexts, which provides the basis for the second section and its more specialized analysis of camels' role in local star calendars. The whole chapter then concludes with a final section offering a set of interpretations.

\section{USING CAMELS IN THEIR MATERIAL CONTEXTS}

The lowlands of the Red Sea coastal plains (see graph 29) are among the world's hottest areas. Mean annual temperatures range between 29 and $30^{\circ} \mathrm{C}$ and thus are slightly above tropical heat. For the Yemeni Tihama, and for the Saudi Tihäma to the south of Jidda, the figures for mean annual rainfall in the late 1970s were 50-300 mm (Abdulfattah 1981:36; Map 3, Stone 1985:9). In the Tihāma adjoining southern Hijāz and northern 'Asìr, most of a year's precipitation concentrates in the two solar months of August and January. Anticipating the rainy seasons could thus be essential for the economic and, in fact, for the physical survival of local households. A wide range of star calendars, of mnemonic references and other related observations therefore represent widespread intellectual resources among local residents in this regard. This cognitive legacy also includes local folk notions about dromedaries' specific relation to the climate at the end of the summer drought season. Camels' behavior was also said to indicate the return of the Pleiades, as the main constellation in the most widespread local calendar. As one of the most conspicuous constellations in the sky, the Pleiades play an important part in many folk calendars

\footnotetext{
${ }^{1}$ This cooperation between King Saud University (Riyad) and the University of Vienna was funded by the Kingdom of Saudi Arabia's Ministry of Higher Education and the Austrian Science Fund (FWF). The main results were edited by Walter Dostal (1983a; 2006). I would like to thank the editors of this volume for initiating the conference and the ensuing publication, and in addition, Najwa Adra, Dan Varisco (Long Island, N.Y.) and Johann Heiss (Vienna) for their helpful comments on a first draft of this text. Host Kopp (Erlangen-Nürnberg) and his team generously contributed the accompanying map. This chapter follows Arabic transliteration rules of the International Journal of Middle Eastern Studies except for Anglicized terms (e.g., Mecca).
} 
all around the globe. The specific ways in which regional folk calendars in south-western Arabia operate will be discussed in more detail in the second section. But in order to understand how the Pleiades are symbolically associated with conceptions of the camel, this opening section first has to provide an overview of camels' usage and significance in historical, practical and symbolic contexts of the region.

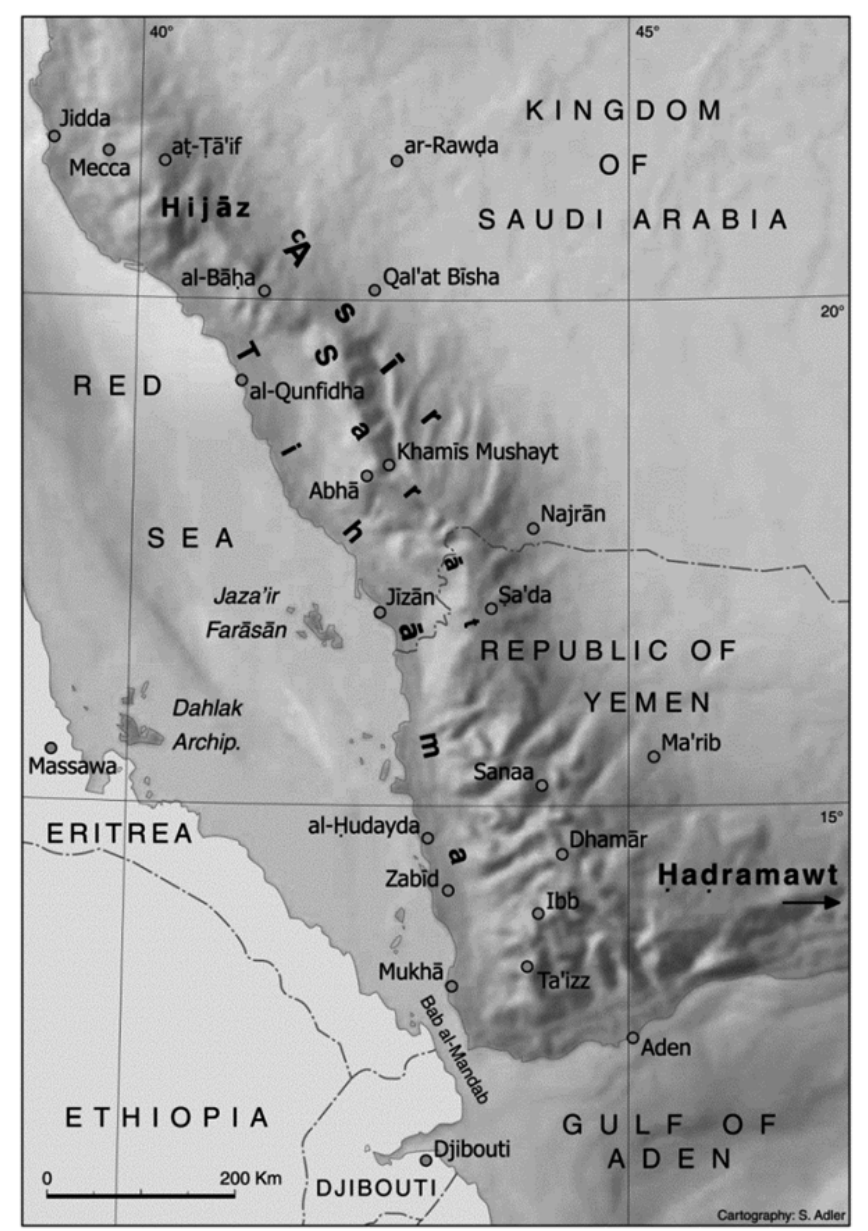

Graph 29: South Western Arabia: The coastal plain along the Red Sea coast (Tihāma) is home to various folk myths, blending knowledge and legend about the camel and its role for stellar lore and for fertility.

At first sight it may appear counter-intuitive that the camel should play such a prominent role in local symbolic conceptions with regard to rain, to annual cycles of precipitation and to local life in general within a region that has never been particularly well known for its camel-raising traditions. It is true that dromedaries from southwest Arabia's coastal lowlands hardly ever played any famous role at the peninsula's courts as racing camels, or for their meat quality in the main markets of the region. A brief outline of the historical and material contexts, however, will demonstrate that their economic role within the region has been significant and, in fact, quite indispensable.

\section{BEYOND THE LOCAL: CAMELS AND TRADING ROUTES}

For long-distance trade, the north-south routes through today's Arab Peninsula were much more important during most historical periods than those between east and west. Three such longdistance routes were used since antiquity. All of them ran roughly parallel to each other and to the eastern coastline along the Red Sea. The westernmost of these three routes in fact was by sea and followed the coastline on water. The other two were by land, the easternmost following the lower eastern slopes of south-west Arabia's fertile mountain ranges (Sarāt) through the transition zones towards inner Arabia. By contrast, the central route led through the Tihamma coastal plains. ${ }^{2}$ Among these three main north-south routes, the western one by sea and the eastern one along the lower east of the Sarāt mountain ranges were used more frequently than the central routes through the Tihäma, as is already testified by documents from late antiquity for the socalled frankincense or incense routes (Müller 1978). The three north-south routes had that name in late antiquity for their relevance with regard to specific luxury goods such as incense. Yet the significance of those routes went far beyond that, for in general they connected the commerce and economies of Mediterranean antiquity with those bordering the Indian Ocean. These routes

\footnotetext{
${ }^{2}$ For a discussion of these routes up to medieval times see the article (including the map) by Johann Heiss in this volume.
} 
were therefore not only essential for exchanging luxury goods such as incense or gems, but also some local products for everyday use such as honey or leather (Gingrich 2006a).

Commercial handbooks from late antiquity such as the Periplus Maris Erythrei mention many Red Sea ports. These certainly served the main commercial transactions in a north-south direction. Yet in addition they also must have served as points of departure and destination in the east-west directions, connecting the much more fertile regions of the Sarāt highlands with the small ports along the coast. In Islamic times, pilgrimage to Mecca had a twofold effect on the region in our present topical contexts: pilgrimage implied a rising frequency of travel, and thus increased the demand for camels for transportation, and pilgrimage also represented a growing demand for slaughter beasts, ${ }^{3}$ with unavoidable repercussions upon a region in the southern neighborhood of Mecca such as the Tihäma. The emergence of Islam and of Muslim pilgrimage therefore had a substantial impact on the significance of camels, through the increasing role of major regional ports and on their hinterland. This has also been demonstrated for the later Middle Ages for various smaller port towns such as al-Qunfidha (Gingrich 2005), al$M u k h \bar{a}$ (Becker/Höhfeld/Kopp 1979) and others. These developments and their impact connected the Tihama between Jidda and al-Hudayda to regional and international trade in both directions, i.e. by providing important outlets for local products and by opening up the region to goods and ideas from outside. Together with demographic shifts from the steppe margins to the eastern slopes of the Sarāt, the eastern north-south route changed as well, while the Tihama route maintained its significance. As the essential means of overland transportation along these routes, and as a main provider of local products such as honey, hides, or wood, the dromedary's role in the Tihāma' s economic history can thus hardly be overrated (see picture 40). In the Ottoman period, and particularly so after the opening of the Suez Canal in 1867, camels' significance may have reached their plateau, which continued to an extent after the 1918 collapse of Ottoman administration into the 20th century's first decades of independent Yemeni and Saudi rule in the Tihama (Gingrich 2006b). Only with the introduction of modern roads and of cars since the 1950s did the dromedary's role in this region substantially decrease.

\section{REGIONAL CONDITIONS FOR RAISING DROMEDARIES}

The groups of villages where in 1981/82 I was told the local stories by the elderly men mentioned above about the camel's sensitivity to the "return of the "Pleiades" were all located at the western end of the Tihama lowlands. In their eastern parts, these lowlands then rise to the socalled hilly and mountain Tihäma (Abdulfattah 1981). Using and raising camels is widespread in the Tihāma lowlands, while due to their zoological properties, in the hilly Tihäma the use of camels is less frequent and the raising of camels is virtually non-existent. Instead, cattle in the hilly and mountain Tihäma assume some of the main functions of the Tihāma lowland camel i.e. as draft animals, providers of milk, dung, meat and leather, and as a means of transport over shorter distances. In a very pragmatic general sense this resulted in a widely shared local opinion that will be important for understanding the final section of this text: every rural Tihäma resident knew that "the bull is the camel of the mountains, and the camel is the bull of the lowlands". Cattle (or "bull") and camel therefore occupied very similar and in fact logically almost identical and interchangeable positions in the everyday experience of the residents in these two adjoining Tihāma regions.

The vast but arid Tihāma lowlands are less fertile and thinly populated. They are geographically sub-divided by the parallel courses of wādīs, which all roughly follow an east-west direction. Carrying occasional floods from the mountains in the east during the rainy seasons, these $w \bar{a} d \bar{\imath} s$ also hold more moisture during the rest of the year than the steppe zones between them.

\footnotetext{
${ }^{3}$ If affordable, the pilgrimage to Mecca represents one of the main obligations for Muslim believers (therefore also called "pillars" of Islam), and ritual procedures of pilgrimage still require appropriate sacrificial slaughterings at the right time and site.
} 
The Tihäma thus can be seen as a north-south sequence of parallel wādis running through the mountain and hilly Tihāma in the east and leading to their mouths at the Red Sea shore in the west, where a port often has the same name as the $w \bar{a} d \bar{l}$. From north to south, this sequence includes Wādī al-Lìth, 'Iyār, al-Dawqa, Ahsiba, Yabā', Halì, Arīk, Rìm,'Itwad, Baysh, Jīzān, and many more. The course of each $w \bar{a} d \bar{l}$ also provided the preferred routes for east-west travel.

Since the areas along the banks of these wādīs contain more moisture and wells, they are the privileged location for permanent rural settlements, for markets and for cultivation wherever possible. In consequence, these also are the areas for milling, for caravan quarters, and for the fenced enclosures where camels are kept overnight. By contrast, the camels' main grazing areas are off these settlement areas, i.e. either inside the wād $\bar{\imath}$ beds or in the drier steppe zones. In the 1980s, major sections of the rural Saudi Tihàma population lived in permanent settlements, but smaller groups were semi-nomadic or nomadic. Typically, Tihäma nomads and semi-nomads do not use the inner Arabian black tent, but mobile straw huts of various forms (Gingrich 2006c).

\section{WELLS AND MILLS}

This first section can be concluded by highlighting two functions of Tihāma lowland camel as a draft animal that was highly relevant before the introduction of other forms of energy, both remaining widespread well into the early 1980s. This concerns wells and mills. By contrast, tilling the soil required no draft animal, since the hoe and digging stick were most frequently used by hand in the Saudi lowlands. Plowing, or rather cutting the soil by use of the ard, was practiced only in the hills and mountains, where camels occasionally were used as draft animals for that purpose as well.

Well construction includes the pulley or draw wheel as the most robust and central feature, around which the well rope is used to pull up the water container by means of animal draft energy (Gingrich/Heiss 1986 for examples from Yemen's northernmost areas). In their technical design, traditional Tihama wells followed the same principle common in the highlands of Yemen and 'Asìr. By contrast, sesame is a crop that has been relatively specific to the Tihama lowlands for many centuries (Varisco 1994:181, 195-196), but through regional trade sesame and sesame oil also play an important role in the daily lives of the highlands. The production of the oil usually takes place near the centers of sesame cultivation. The owner of a sesame mill is often a specialist serving a whole village or group of villages. In this case, the camel often wears blinkers as a protection against the circular redundancy of the operation (see picture 41-43). In short, until recently the camel was essential for Tihàma lowland residents not only for transportation and commerce, but also for providing access to two main ingredients of their life - to water and to oil.

For the Tihama population, the camel thus provided a means of material access to water and oil, the key to commerce and wealth, and it remains a main sacrificial animal. Their far-reaching material and symbolic significance provides the basic insights to now also understand camels' role in a much more specific dimension of regional cultural life.

\section{CALENDAR SYMBOLISM}

It should be clarified from the outset that folk calendars always combine legends and empirical observation, i.e. folk astrology and folk astronomy, in ways that are common for star lore. As already mentioned, as in many other regions of the world, the Pleiades play a central role in regional star lore and folk calendars. These regional folk calendars address a symbolic association between the Pleiades, the dromedary and the coming of the rainy season. ${ }^{4}$ This symbolic

\footnotetext{
${ }^{4}$ Daniel Varisco (personal communication, 31 Jan., 2011) indicates that the famous South Arabian navigator Ibn Majīd refers to ways in which the Pleiades have been imagined, one being that of a she-camel (Tibbetts 1979:83).
} 
association was repeatedly presented to me in the verbal form of a stereotypical tale, for which I shall here use the term "standardized narrative". This is a standard form of narration which therefore includes combinations of empirical observation and legends. Scrutinizing a standardized narration in this form makes it possible to subject it to anthropology's critical analysis of myth. In my translation this standardized narrative basically went like this:

When the Pleiades are concealed (law istikannat al-Thurayya) the season is very dry. During these days man and woman should not sleep together, and the soil should not be opened. When the Pleiades then slowly come back in the eastern morning, man and woman do not notice it at first, but the animals will. The first creature to notice the return of the Pleiades is the snake (al-hanash). Some days later, the goat notices and starts to tremble (yuwahwah al-tays). Soon after that, the camel notices the return of the Pleiades too. The camel then stares all the time at the house of man and wife. Only after the camel will humans also sense that the Pleiades are returning. Then the moist season is not far away any more.

The standardized narrative is therefore built on an anthropocentric and geocentric perspective. This narrative includes three interrelated themes or main topical elements: a) stars and stellar constellations as indicators of agricultural star calendars; b) a number of related normative rules or sets of moral regulations for humans. These two elements are then combined with c) several narrative statements about animals.

These three main topical elements will now be discussed consecutively in this present section.

\section{REFERENCE TO STELLAR CALENDARS}

The main temporal reference is directly related to the setting and rising of the Pleiades. Since by their shape and location the Pleiades are a particularly conspicuous constellation, their observation is quite common in many different parts of the globe throughout various periods of history. Yet in this particular regional context, such a reference is an explicit indication of south-west Arabia's most widespread type of agricultural folk calendar, i.e. the anwā' al-zirā' a or ma 'älim al-zirā'a (agricultural markers).

My original question about the $a n w \bar{a}$ ' actually elicited the standardized narrative with its three elements, before my interlocutors would elaborate any details about star lore. Based on earlier publications on this topic (Gingrich 1994, 1997, 2006a) it will suffice in the present context to point out the following: according to most south-west Arabian star calendars, the Pleiades are seen as the "leader" or the "head" of a whole series of ecliptic stars and constellations that are the "followers". The first morning rising of each of these stars or constellations introduces a period of 13-14 days and nights, the period being named after the stellar name. In the south-western parts of Saudi Arabia, no written or printed almanacs are used for these purposes as is the case in central Yemen (Varisco 1994). In most written almanacs and treatises, the $a n w \bar{a}$ ' are presented as a formalized series of 28 constellations that seems to be inspired from other literary sources (al-'Ansī 1998, Varisco 1997). In practical life, the number of observed and known anwā' constellations is always less than 14 and corresponds to the main periods of agricultural activity. Often aided by rhymes and star proverbs, one would therefore associate a specific star name with a specific activity; e.g. the star group of "al-Jabha" would be locally known as the time of preparing the sesame fields, while a couple of weeks later, "al-Sarfa" is known as "sesame sowing time." Star names in the Tihama often refer to risings or settings in the morning: people would enjoy the cooler morning air while sitting either on their house roofs or in front of their straw huts, drinking coffee and commenting to each other on the current stellar rising or setting just before sunrise. This kind of local knowledge is passed on from one generation to the next among interested laypersons and experts. In some regions of the Tihâma, these forms of knowledge are accessible to everybody who is interested, while in others they are restricted to experts and their pupils. Restricted expert knowledge is more explicitly connected to literary sources (Gingrich 1994:205). 
In some areas of the Tihäma of southern Hijäz and 'Asìr, the whole chain of ecliptic stars that "follow" the Pleiades also is perceived as the "body" of the Pleiades, which are then seen as the "head" of a female figure (Gingrich 1997, see also note 4 in this text). By its visual logic and by its popularity among common rural practitioners, the anwā' system thus differs markedly from the manāzil or lunar mansions. Lunar mansions (i.e. specific conjunctions between the moon and certain ecliptic stars or star groups) are already mentioned in the Qur'ān, reference to the anwā' can be found in the Hadīth. Observation of the anwā' therefore meets no objection from Muslim scholars and theologians (Varisco 1997). It is well understood by them that in view of the Islamic lunar calendar, local residents always needed additional time referents that would orientate them through the solar year and its seasonal cycles.

\section{MORAL RULES FOR HUMANS}

For each of these main stars and constellations that are part of the agricultural and folk calendar anwā' al-zirā ' $a$, there is a period during the solar year when they cannot be seen from a given geographical location. At the latitudes of the Tihâma the period between a star group's last evening setting (its "disappearance") and its first morning rising (its "return") occurs for the Pleiades in late spring/early summer. Depending on local conditions of visibility above the horizon, this period may last up to two months. The return of the Pleiades therefore occurs about one month before the summer monsoons. All climatic data for these regions indicate that winter cyclones as well as spring and summer monsoons set in with a relatively high rate of regularity and predictability. Taking the return of the Pleiades as a good and reliable indicator for the imminence of the summer monsoons is therefore the result of useful folk astronomical knowledge and experience. In this sense, the Pleiades are actually (used and interpreted as) a sign of fertility, as is commonly noted already in early anwā' texts beginning with the 9th century CE including Ibn Qutayba (al-Dīnawarī) and Qutrub (Kunitzsch 1961, Varisco 1997). Seeing the Pleiades' absence as a period of taboos and evil spells, however, has more to do with folk astrology. Local terminology refers to this general period as al-Kinna (the "concealed" period of the Pleiades) or rather, in a transliteration of the region's prevailing dialect pronunciation, "am Činna." This period is associated with a twofold set of taboos for humans: they should not cultivate their fields, and married couples also should abstain from the pleasures of sex - particularly during the first 13 days of am Činna, called ayyām al-kabāt. The common denominator in both taboos is obviously an interdiction on any activities related to fertility; the absence of the Pleiades thus is seen as a bad time for fertility-related activities in humans and fields. Since the period of am Cinna certainly is the driest and hottest season of the year, the twofold taboo does not impose too serious a sacrifice upon those who observe it. Still, the implication is ominous and claims that any violation might result in disaster and bad luck.

\section{NARRATIVE STATEMENTS: STELLAR CONSTELLATIONS AND ANIMAL BEHAVIOR}

The standard narrative's third theme, as identified earlier in this section, claims to be descriptive of animals' behavior during the final period of am Činna and the initial weeks thereafter. In a temporal sense, these claims therefore entail a prediction for a time sequence following the appropriate behavior of humans with regard to the taboos of am Činna. From a logical perspective, this represents a best-case scenario that describes what allegedly may be observed if things go well. The best-case scenario thus establishes an order of creatures' sensitivities to the return of the rain, in which humans come last and the snake comes first. The particular role of the snake in this element of the standardized narrative strongly emphasizes the non-empirical, mythological character of the overall, animal-related third element. Humans do not regularly observe snakes in this area at all, but merely talk about them quite often, perceiving them as guardians of springs and wells. This element of the standardized narrative therefore positions a nonobservable phenomenon at one extreme of a scale: the snake is featured as the creature that is most sensitive to the imminence of rain, and simultaneously as the animal at the greatest dis- 
tance from humans. In fact, the snake is the only wild, non-domesticated being on this scale at all.

We may thus conclude the second section of this chapter by returning to the Tihama dromedary and to its role in the standardized narrative. I have pointed out that this narrative combines astronomy and astrology, pragmatic experience and legendary fiction into a mythological structure. That structure situates the camel between humans and their domesticated life at one end of the scale and the snake as an appreciated element of wild life at the other. The myth argues that if humans do not violate taboos of fertility, then the rains will come after the Pleiades return. Other creatures will be aware of this long before humans, the snake most importantly. Yet even before humans grasp that the season is actually changing towards rain, the camel will notice it and will tell them: the standard narrative says that once the camel notices the imminent return of the Pleiades it will stare at the farmer's house or hut.

\section{CONCLUSIONS AND INTERPRETATION}

The Tihäma stories about the camel's sensitivity to the return of the Pleiades and to the coming of the rainy season, which is demonstrated by the camel staring at the farmer's house, now allow presentist as well as historicist lines of interpretation.

In a presentist mode of reasoning, camels continued to play a relatively significant part in the local and regional economies of the Tihama lowlands until the early 1980s. Camels were part of local commerce, they provided important materials for local consumption and their use as draft animals was essential in maintaining access to water and to sesame oil. In addition, they played an eminent symbolic role for local prestige and for religious rituals. The fact that they should also play a relatively significant role in association with local $a n w \bar{a}$ ' calendars was thus entirely in line with their significance in all other aspects of everyday life. Camels were important for agricultural fertility, and the Pleiades indicated a season of increased agricultural fertility.

Through the anwā' agricultural folk calendars, the times of am Činna are established as a minor folk taboo period during the weeks when the Pleiades are invisible. Because of its lunar orientation, the Islamic calendar actually makes additional seasonal - solar and/or stellar forms of time reckoning unavoidable and necessary. Although the Islamic calendar has its own regular periods of abstention and of fasting, Islam therefore does not oppose the observance of the anwā', nor does the folk taboo period contradict Ramadan. When the Pleiades return after the driest and hottest season of the year, it is then hoped that the rains will come soon: camels are believed to display a special sensitivity in this regard.

A historicist line of wider interpretations would add the following thoughts: the camel and the bull occupy analogous positions in the rural Tihäma population's imaginary universe, since in many ways the camel is seen as the "bull of the Tihäma lowlands." In this imaginary sense, both animals are interchangeable. The standardized narrative therefore positions the camel/bull as particularly close to humans' domestic life and the snake at an extreme distance. Both are seen as imaginary animals with a specifically meaningful relationship to humans and to the return of the Pleiades as a symbol of water and life. Archeological evidence has richly demonstrated the importance of snake and bull as ritual animals and as sacred beings in the ancient south Arabian pantheon of pre-Islamic times, when they held intermediate positions between humans and the gods (Ryckmans 1987, Dostal 1983b). In the strictly monotheist frame of Islam, that previously elevated status later became subordinate to humans, as an integral part of Creation. Yet some reflection of the ancient legacy seems to persist in today's appreciation by local people for these animals' special association to fertility. In addition to its presentist relevance, the standardized narrative could therefore also include elements of ancient South Arabian mythological beliefs and legends. 
And after all, one final question has to remain open: if camels are so much better than humans in anticipating water at a spatial distance, who would doubt that there might be some camels that could do the same from a temporal distance as well?

\section{REFERENCES}

Abdulfattah, K (1981): Mountain Farmer and Fellah in 'Asīr, Southwest Saudi Arabia: The Conditions of Agriculture in a Traditional Society. Erlanger geographische Arbeiten Sonderband 12, Erlangen: Palm \& Enke

al-`Ansī, Yaḥyā (1998): al-Ma'ālim al-Zirā’a fī l-Yaman. San'ā’': ACYS-CFEY

Becker, H/Höhfeld, V/Kopp, H (1979): Kaffee aus Arabien: Der Bedeutungswandel eines Weltwirtschaftsgutes und seine siedlungsgeographische Konsequenz an der Trockengrenze der Ökumene. Erdkundliches Wissen 46, Wiesbaden: Steiner

Dostal, W (1983a): Ethnographic Atlas of 'Asīr: Preliminary Report, with Contributions by A. Gingrich and J. Riedl. Sitzungsberichte der philosophisch-historischen Klasse Bd. 406, Vienna: Austrian Academy of Sciences Press

--- (1983b): "Some Remarks on the Ritual Significance of the Bull in Pre-Islamic South Arabia", in: Bidwell, RL/ Smith, GR (eds.): Arabian and Islamic Studies: Articles Presented to RB Serjeant on the Occasion of his Retirement from the Sir Thomas Adam's Chair of Arabic at the University of Cambridge. London/New York: Longman, pp. 196-213

--- (ed.) (2006): Tribale Gesellschaften der südwestlichen Regionen des Königreiches Saudi Arabien. Sozialanthropologische Untersuchungen. Veröffentlichungen zur Sozialanthropologie Bd. 8, Sitzungsberichte der philosophisch-historischen Klasse Bd. 732, Vienna: Austrian Academy of Sciences Press

Gingrich, A (1994): Südwestarabische Sternenkalender: Eine ethnologische Studie zu Struktur, Kontext und regionalem Vergleich des tribalen Agrarkalenders der Munebbih im Jemen. Wiener Beiträge zur Ethnologie und Anthropologie Bd. 7, Vienna: WUV

--- (1997): "Female Form, Evil Times: Local concepts related to the Pleiades in the ethnography of Southern Hijāz", in: Stiegner, RG (ed.): Südarabien Interdisziplinär: In memoriam Maria Höfner. Aktualisierte Beiträge zum 1. Internationalen Südarabien-Symposium an der Universität Graz, mit kurzen Einführungen zu Sprach- und Kulturgeschichte, Graz: Leykam, pp. 45-53

--- (2005): "Norm und Praxis: Zur Ordnung des Raumes am Beispiel der Siedlungsgeschichte von al-Qunfidha", in: Heiss, J (ed.): Veränderung und Stabilität: Normen und Werte in Islamischen Gesellschaften. Veröffentlichungen zur Sozialanthropologie Bd.7, Sitzungsberichte der philosophischhistorischen Klasse Bd. 729, Vienna: Austrian Academy of Sciences Press, pp. 91-119

--- (2006a): "Honig und tribale Gesellschaft: Historischer Hintergrund, sozialer Gebrauchund traditionelle Erzeugung im südlichen Hijāz", in: Dostal, W (ed.): Tribale Gesellschaften der südwestlichen Regionen des Königreiches Saudi Arabien. Sozialanthropologische Untersuchungen. Veröffentlichungen zur Sozialanthropologie Bd. 8, Sitzungsberichte der philosophisch-historischen Klasse Bd. 732, Vienna: Austrian Academy of Sciences Press, pp. 173-215

--- (2006b): "Ländliche Sternenkalender aus dem südlichen Hijāz. (Mit drei Anhängen zu örtlichen Kalendern aus dem Norden des 'Asīr und aus Jīzān von A.R. Aloshban, R.B. Serjeant und J. Lambert”, in: Dostal, W (ed.): Tribale Gesellschaften der südwestlichen Regionen des Königreiches Saudi Arabien. Sozialanthropologische Untersuchungen. Veröffentlichungen zur Sozialanthropologie Bd. 8, Sitzungsberichte der philosophisch-historischen Klasse Bd. 732, Vienna: Austrian Academy of Sciences Press, pp. 407-467, 638

--- (2006c): "Wohnarchitektur im südwestlichen Saudi Arabien: Lokale Zeugnisse historischer Interaktionen mit Nachbarn, Herrschern und Fremden", in: Dostal, W (ed.): Tribale Gesellschaften der südwestlichen Regionen des Königreiches Saudi Arabien. Sozialanthropologische Untersuchungen. Veröffentlichungen zur Sozialanthropologie Bd. 8, Sitzungsberichte der philosophischhistorischen Klasse Bd. 732, Vienna: Austrian Academy of Sciences Press, pp. 207-406, 576-613, 630-637, 676-682

---/Heiss, J (1986): Beiträge zur Ethnographie der Provinz Sa 'da (Nordjemen): Aspekte der traditionellen materiellen Kultur in bäuerlichen Stammesgesellschaften. Sitzungsberichte der philosophischhistorischen Klasse Bd. 462, Vienna: Austrian Academy of Sciences Press

Kunitzsch, P (1961): Untersuchungen zur Sternennomenklatur der Araber. Wiesbaden: Harrassowitz

Müller, WW (1978): Weihrauch: Ein arabisches Produkt und seine Bedeutung in der Antike. Pauly-Wissowas Realencyclopädie der klassischen Altertumswissenschaft, Supplement-Band XV. Munich: Alfred Druckenmüller Verlag

Ryckmans, J (1987): “Die Altsüdarabische Religion”, in: Daum, W (ed.): Jemen: 3000 Jahre Kunst und Kultur des Glücklichen Arabien, Innsbruck/Frankfurt: Pinguin-Umschau, pp. 111-115

Stone, F (ed.) (1985): Studies on the Tihāmah: The Report of the Tihāmah Expedition 1982 and Related Papers. Burnt Mill: Longman 
Tibbetts, GR (1979): A Study of the Arabic Texts Containing Material on South-East Asia. Leiden: Brill

Varisco, D (1994): Medieval Agriculture and Islamic Science: The Almanac of a Yemeni Sultan. Seattle: University of Washington Press

--- (1997): Medieval Folk Astronomy and Agriculture in Arabia and in the Yemen. Variorum Collected Studies Series, Aldershot/Hampshire: Ashgate 
